\title{
ANALYSIS OF WELDABILITY OF DUAL-PHASE STEEL USED IN AUTOMOTIVE INDUSTRY
}

\begin{abstract}
This paper deals with the problems of weldability of high strength dual-phase steel sheets used in the car body production. The properties of the joints made by resistance spot welding (RSW) and laser welding were analysed. The two grades of dual-phase steels such as DP 600 and DP 800 were used. The joints were made by overlapping of two sheets in the method 21 according to EN ISO 4063 (RSW), and as butt weld without a gap by laser welding (method 52 in EN ISO 4063). The parameters of RSW and laser welding were chosen according to the recommendations of IIW. The quality of welded joints was evaluated by visual control, static tension test, and a microstructural analysis of the joints on the light microscopy.
\end{abstract}

Keywords: spot welding, laser welding, dual-phase steel

\section{Introduction}

The production of automobiles in the EU significantly increases in recent years. Increasing the production leads to the application of new advanced materials in order to minimize the costs of production, as well as to produce fuelefficient and ecological products, enhancing comfort and security of car passengers. The car producers also utilize the various combinations of materials, such as most used steel sheets of drawing grade quality as well as advanced high-strength steel sheets (AHSS) or high-strength low alloy (HSLA) steels $[1,2]$. It is necessary not only to produce car body parts but to join them into a complex structure as well. Mainly resistance spot welding and laser welding are the joining method used to join thin-walled assemblies in automotive industry. Therefore, the research into weldability of these materials is important, especially optimization of welding properties. The galvanized steel sheets with corrosion resistance have been used in automobile industry, replacing cold rolled steel sheets as auto body materials to improve the corrosion resistance

\footnotetext{
1 Autor do korespondencji/corresponding author: Ján Viňáš, Technical University of Košice, Letná 9, 04200 Košice, Slovakia, e-mail: jan.vinas@tuke.sk

${ }^{2}$ Luboš Kaščák, Technical University of Košice, Slovakia e-mail: lubos.kascak@tuke.sk
} 
and overall service life of vehicles [3, 4]. Advanced high-strength steels for automotive applications have been the aim of research and the development in the recent years. Their introduction in car bodies allows to reduce their weight and improve the car safety. Nevertheless, the weldability of AHSS is an important issue since cars typically contain thousands of spot welds [5, 6]. Ferrite-martensite dual-phase (DP) steels are some of the most common AHSSs, which are currently used in automotive industry. Their microstructure offers a suitable combination of strength and formability. The term dual-phase steel refers to the predominance of two lattices, the body-centered-cubic (bcc) ferrite and the relatively harder body-centered-tetragonal (bct) martensite. These two lattices are produced by some annealing in the range of the upper $\left(\mathrm{A}_{3}\right)$ and lower $\left(\mathrm{A}_{1}\right)$ transformation temperatures, where austenite and ferrite are formed, and a subsequent rapid cooling where the austenite is eventually transformed into martensite [7,8].

The paper deals with the analysis of possibility of welding of highstrength dual-phase steels sheets DP600 and DP 800 by resistance spot welding and laser welding.

\section{Experimental procedure}

Within the experimental work, the welded samples were prepared in the laboratory using the two most commonly used method of welding in automotive industry. The first method of joining was resistance spot welding, carried out on the programmable pneumatic welding machine BPK 20 with welding electrode tips of $\varnothing 5 \mathrm{~mm}$. An influence of welding current as the main parameter of resistance spot welding on the quality of spot welds was observed. The spot weld was made by overlapping of the steel sheets in position PA according to EN ISO 6947 standard. The second method of joining was laser welding using $\mathrm{CO}_{2} \mathrm{AF} 8 \mathrm{P}$ laser with maximum output of $8 \mathrm{~kW}$. The samples were welded along the sheet width $(800 \mathrm{~mm})$ in position PA according to EN ISO 6947 standard without a gap between the sheets.

Two types of high-strength dual-phase steel sheets DP600 and DP800. These steel sheets with the thickness of $0.8 \mathrm{~mm}$ were hot-dip galvanized. The chemical composition and basic mechanical properties of the welded material are shown in table 1 and table 2, respectively. For each type of welding, five samples were prepared for static tensile test and two samples for metallographic analysis. Labelling of samples was as follows:

- samples A and B: steel sheet DP600 made by resistance spot welding,

- samples C and D: steel sheet DP800 made by resistance spot welding,

- sample E: steel sheet DP600 made by laser welding,

- sample F: steel sheet DP800 made by laser welding. 
Table 1. Chemical composition of welded steel sheets (wt-\%)

\begin{tabular}{|c|c|c|c|c|c|c|c|c|}
\hline & $\mathrm{C}$ & $\mathrm{Mn}$ & $\mathrm{Si}$ & $\mathrm{P}$ & $\mathrm{S}$ & $\mathrm{Al}$ & $\mathrm{Cu}$ & $\mathrm{Cr}$ \\
\cline { 2 - 10 } DP 600 & 0.111 & 1.963 & 0.279 & 0.026 & $<0.002$ & 0.031 & 0.019 & 0.206 \\
\cline { 2 - 9 } & $\mathrm{Mo}$ & $\mathrm{Ni}$ & $\mathrm{V}$ & $\mathrm{Ti}$ & $\mathrm{Nb}$ & $\mathrm{Co}$ & $\mathrm{W}$ & $\mathrm{Fe}$ \\
\cline { 2 - 9 } & $<0.002$ & $<0.002$ & 0.012 & $<0.002$ & 0.020 & 0.017 & 0.005 & $\mathrm{Bal}$ \\
\hline \multirow{5}{*}{ DP 800 } & $\mathrm{C}$ & $\mathrm{Mn}$ & $\mathrm{Si}$ & $\mathrm{P}$ & $\mathrm{S}$ & $\mathrm{Al}$ & $\mathrm{Cu}$ & $\mathrm{Cr}$ \\
\cline { 2 - 9 } & 0.062 & 1.623 & 0.036 & 0.022 & $<0.002$ & 0.086 & 0.119 & 0.247 \\
\cline { 2 - 9 } & $\mathrm{Mo}$ & $\mathrm{Ni}$ & $\mathrm{V}$ & $\mathrm{Ti}$ & $\mathrm{Nb}$ & $\mathrm{Co}$ & $\mathrm{W}$ & $\mathrm{Fe}$ \\
\cline { 2 - 9 } & 0.293 & 0.107 & 0.056 & $<0.002$ & 0.077 & 0.1 & $<0.002$ & $\mathrm{Bal}$ \\
\hline
\end{tabular}

Table 2. Basic mechanical properties of welded materials given by producer

\begin{tabular}{|l|c|c|c|}
\hline \multirow{3}{*}{ Material } & Yield stress & Ultimate strength & Total elongation \\
& $\mathrm{Re}_{\mathrm{e}}$ & $\mathrm{R}_{\mathrm{m}}$ & $\mathrm{A}_{5}$ \\
$\%$
\end{tabular}

The following parameters of resistance spot welding were used:

- pressing force of welding electrodes: $\mathrm{Fz}=4 \mathrm{kN}$,

- welding time: $\mathrm{T}=20$ periods $(1$ period $=0.02 \mathrm{~s}$ ),

- welding current: $\mathrm{I}=4.5 \mathrm{kA}$ for samples $\mathrm{A}$ and $\mathrm{C}$,

$\mathrm{I}=7 \mathrm{kA}$ for samples $\mathrm{B}$ and $\mathrm{D}$.

The following parameters were used for laser welding:

- output: $\mathrm{P}=1700 \mathrm{~W}$,

- laser mode: TEM 10 - Gauss,

- gas: Ar 12 1/min,

- welding speed: $\mathrm{v}_{\mathrm{z}}=2000 \mathrm{~mm} / \mathrm{min}$,

- beam focusing: on the top sheet surface $f=0 \div 0.5 \mathrm{~mm}$,

- wave-length: $\lambda=10.6 \mu \mathrm{m}$.

The quality of the welds was evaluated by the visual observation according to EN ISO 17637 recommendations. Furthermore, two different destructive tests of the welds were carried out. The spot welded joints were tested in static tensile test according to STN EN 051122 standard. The welded joints were tested in a tensile test in transverse direction according to STN EN ISO 4136 standard. The influence of parameters on the microstructure changes in the welded metal and heat-affected zone (HAZ) was evaluated with the light microscopy using metallographic samples prepared according to EN ISO 17639 standard.

\section{Results and discussion}

The analysis of the quality of welded joints by visual test has not proved the presence of external surface defects on the spot welds. Similarly, the absence of pores, cracks and other defects was observed in laser welds. The 
welds can be classified on the basis of a visual test. The maximum loadbearing capacity of the welded joints and the place of destruction were evaluated by a tensile test. When using the welding current $\mathrm{I}=4.5 \mathrm{kA}$ in joining DP600 steels, the average load-bearing capacity of the spot welds was $8300 \mathrm{~N}$. Increasing the welding current to the value of $\mathrm{I}=7 \mathrm{kA}$ led to increasing the average load-bearing capacity of the joints to the value of $9150 \mathrm{~N}$. The average value of load-bearing capacity of the spot welded DP800 steels using welding current $\mathrm{I}=4.5 \mathrm{kA}$ was $8670 \mathrm{~N}$. Even in these steels the higher average value of load-bearing capacity of $9430 \mathrm{~N}$ was measured when welding current was increased to $\mathrm{I}=7 \mathrm{kA}$, as shown in table 3 .

Table 3. The average values of load-bearing capacity $F_{\max }, R_{e}$ and $R_{m}$ of welded joints (BM - Base Metal, HAZ - Heat-Affected Zone, WM - Weld Metal, FW - Fusion Weld)

\begin{tabular}{|c|c|c|c|}
\hline Sample & $F_{\max }, \mathrm{N}$ & Type of joint & Destruction \\
\hline A & 8300 & FW & HAZ \\
\hline B & 9150 & FW & HAZ \\
\hline C & 8670 & FW & HAZ \\
\hline D & 9430 & FW & HAZ \\
\hline \multicolumn{5}{|r|}{ Sample } & Re, MPa & Rm, MPa & Destruction \\
\hline E & 372 & 620 & BM \\
\hline F & 467 & 788 & BM \\
\hline
\end{tabular}

The measured values of $R_{e}$ and $R_{m}$ in laser welds of both dual-phase steel sheets (Table 3 ) exceeded the minimum values of the base material declared by the sheet producer (Table 2). In the tensile test, the destruction of the joints occurred outside the laser weld, in the base material. The minimum measured average value of $R_{m}$ in the case of the sample E made of DP600 steel sheets was $620 \mathrm{MPa}$ and in the case of the sample F made of DP800 steel sheets was $788 \mathrm{MPa}$. The results of the macroscopic analysis are presented in figures 1-4. No presence of cavities and pores in the weld nugget was observed in the samples $\mathrm{A}$ and $\mathrm{C}$ (Figs. 1 and 3) made by resistance spot welding. Increasing the welding current led to the changes in dimensions of the weld nugget, heat affected zone as well as the occurrence of cavities in the middle of the weld nugget (Figs. 2 and 4). The typical dendritic growth of weld metal was observed on weld structures. In the weld metal of laser welded samples in both DP600 and DP800 steel sheets no internal defects were observed (Fig. 5). The microstructure of the sample A with the transition of base metal via heataffected zone to the weld nugget is shown in Fig. 6. The changes in grain size, the orientation of grains and phase were observed. It was found that a multiphase structure is composed of fine-grained martensite, bainite and ferrite. Figure 7 shows a cavity in the middle of the weld nugget of the sample D, which occurred due to shrinkage of weld metal during the solidification process. 


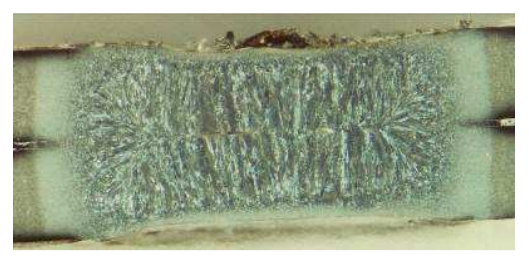

Fig. 1 Macrostructure of sample A (DP 600)

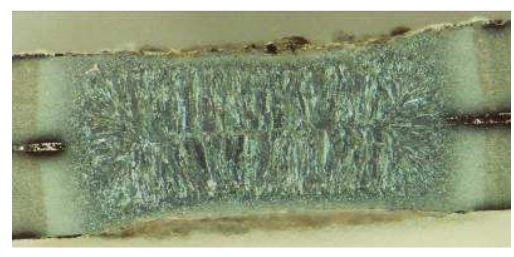

Fig. 3 Macrostructure of sample C (DP Fig. 4 Macrostructure of sample D (DP $800)$

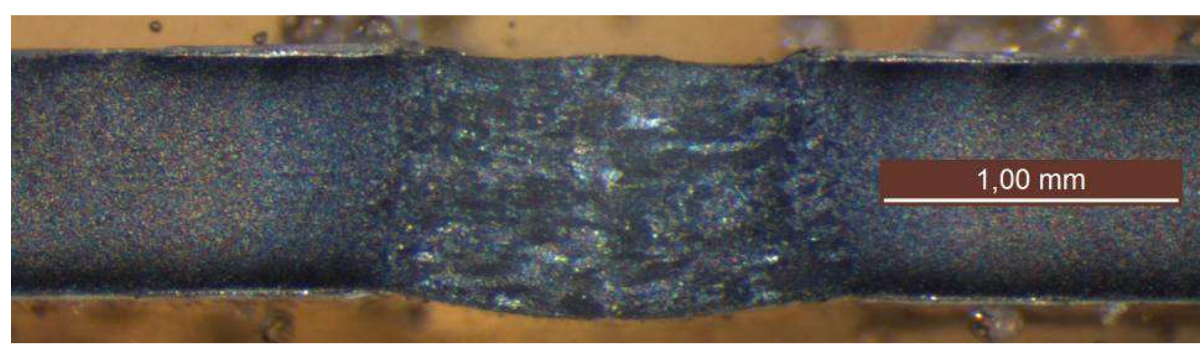

Fig. 5. Laser weld of DP 600

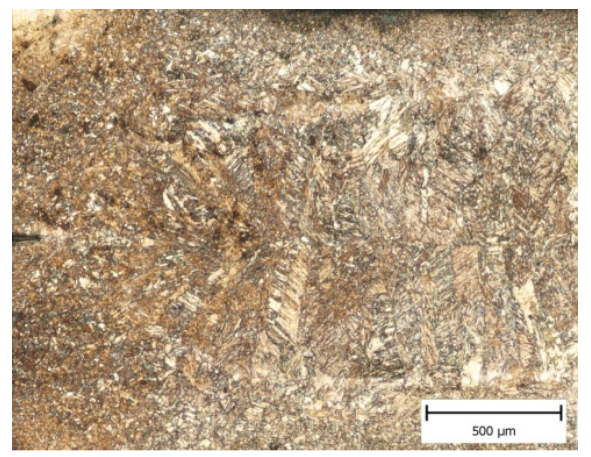

Fig. 6 Weld microstructure of sample A (DP 600)

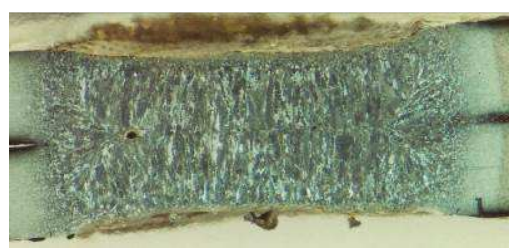

Fig. 2 Macrostructure of sample B (DP 600)

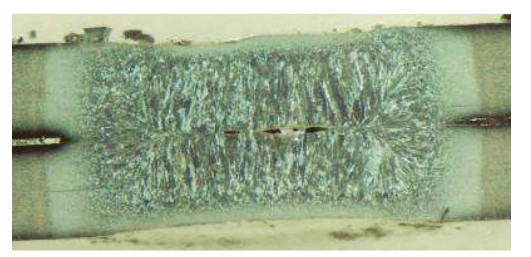

800)

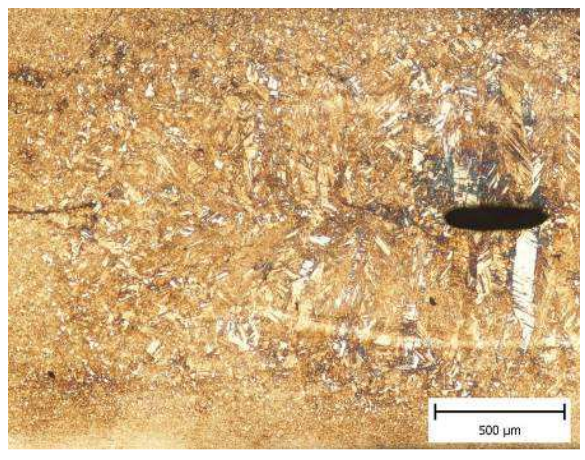

Fig. 7 Weld microstructure of sample D (DP 800) 
The microstructure of the base material of both DP600 (Fig. 8) and DP800 steels is composed by ferritic matrix with dispersed fine-grained martensite. The microstructure of HAZ of lase welds of DP800 steel (Fig. 9) is composed of multiphase microstructure of fine-grained martensite and bainite in the ferritic matrix. Concerning the used welding parameters and the thickness of the sheets the width of the HAZ in both materials was the same. The microstructure of weld metal of laser welds (Fig. 10) is composed primarily of the coarse-grained lamellar martensite and bainite due to rapid cooling.

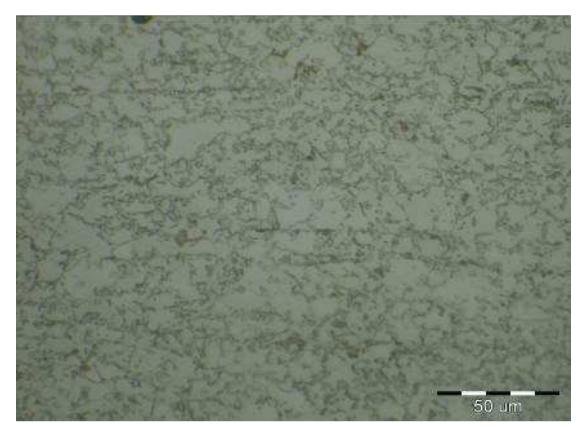

Fig. 8. Base material of DP 600

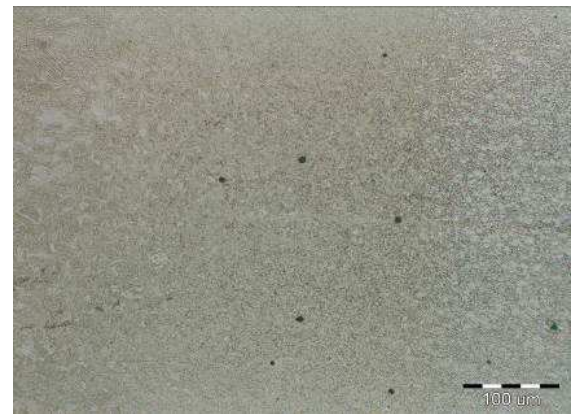

Fig. 9. Microstructure of HAZ of sample F

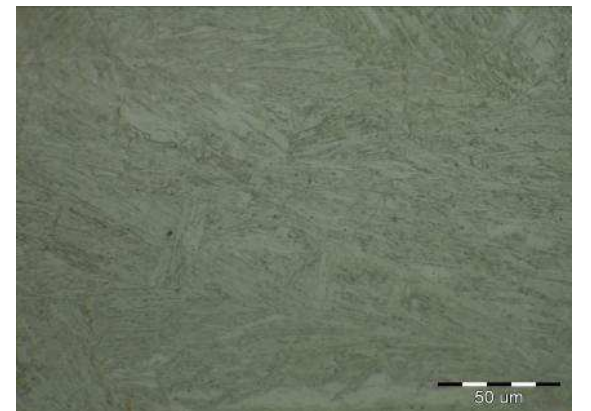

Fig. 10. Microstructure of laser weld metal of sample $\mathrm{F}$

\section{Conclusions}

The application of high-strength steels in car body production is still increasing because of weight reduction of cars. Development of the construction of laser welders and the reducing economic demands of the welding process is increasingly attractive to the producers. On the other hand, these progressive high-speed welding methods require optimization of welding parameters, especially in welding of difficult to weld materials. The methods also require the application of accurate fixtures ensuring the correct position of the narrow welds, which is common problem in the industry. 
The resistance spot welding of dual-phase steel sheets requires consistent optimization of welding parameters. When using 20 periods of welding time, it is suitable to use low values of welding current $(4.5 \mathrm{kA})$, since no internal defects occur in welding nugget and load-bearing capacity of the joints is sufficient.

The laser welding is a suitable method for joining the dual-phase highstrength steel sheets. Since the weld and heat-affected zone are narrow, no internal defects occur in the weld metal and the load-bearing capacity of the joints is high considering the predominant martensitic microstructure. The load-capacity of laser weld joint is higher than the ultimate tensile strength of welded materials.

\section{Acknowledgement}

This work was supported by the Slovak Research and Development Agency under the contract No. APVV-0273-12.

\section{References}

[1] Mucha J., Kaščák L., Spišák E.: The experimental analysis of forming and strength of Clinch Riveting sheet metal joint made of different materials, Adv. Mech. Eng., 59 (2013) 1-11.

[2] Zhang X., Chen G., Zhang Y., Lai X.: Improvement of resistance spot weldability for dual-phase (DP600) steels using servo gun, J. Mat. Proc. Technol., 209 (2009) 2671-2675.

[3] Hernandez V.H.B., Panda S.K., Okita Y., Zhou N.Y.: A study on heat affected zone softening in resistance spot welded dual phase steel by nanoindentation, J. Mat. Sci., 45 (2010) 1638-1647.

[4] Kašćák L., Brezinová J., Mucha J.: Evaluation of corrosion resistance of galvanized steel sheets used in automotive production, Mat. Sci. Forum, 818 (2015) 141-144.

[5] Dancette S., Fabregue D., Estevez R., Massardier V., Dupuy T., Bouzekri M.: A finite element model for the prediction of Advanced High Strength Steel spot welds fracture, Eng. Fracture Mech., 87 (2012) 48-61.

[6] Kašč́k L., Spišák E., Gajdoš I.: Influence of welding parameters on the quality of resistance spot welded joints of DP600 steels, Key Eng. Mat., 635 (2015) 143146.

[7] Pouranvari M., Marashi S.P.H., Jaber H.L.: DP780 dual-phase-steel spot welds: critical fusion-zone size ensuring the pull-out failure mode, Mat. Technol., 49 (2015) 579-585.

[8] Lifang M., Jiming Y., Dongbing Y., Jinwu L., Genyu C.: Comparative study on $\mathrm{CO}_{2}$ laser overlap welding and resistance spot welding for galvanized steel, Mat. Design, 40 (2012) 433-442. 
ANALIZA ZGRZEWALNOŚCI STALI DWUFAZOWEJ STOSOWANEJ W PRZEMYŚLE MOTORYZACYJNYM

\section{Streszczenie}

Artykuł jest poświęcony problemom zgrzewalności wysokowytrzymałych dwufazowych blach stalowych stosowanych do produkcji karoserii samochodowych. Analizowano właściwości połączeń wykonanych metodami punktowego zgrzewania oporowego (PZO) oraz spawania laserowego. Badania przeprowadzono dla dwóch gatunków blach dwufazowych tj. DP600 oraz DP800. Połączenia zakładkowe blach wykonano zgodnie z metodą 21 ujętą w normie EN ISO 4063. Podczas spawania laserowego blachy łączono metodą na styk bez szczeliny (metoda 52 zgodnie z normą EN ISO 4063). Parametry zgrzewania punktowego oraz spawania laserowego były zgodne z wytycznymi IIW. Ocenę jakości wykonanych połączeń przeprowadzono na podstawie kontroli wzrokowej, statycznego testu rozciągania oraz analizy mikrostrukturalnej połączeń z wykorzystaniem mikroskopii świetlnej.

Słowa kluczowe: zgrzewanie punktowe, spawanie laserowe, stal dwufazowa

DOI: $10.7862 / \mathrm{rm} .2016 .21$

Otrzymano/received: 29.05.2016 r.

Zaakceptowano/accepted: 11.09.2016 r. 